\title{
Social Stratification in Kashmir: A Case Study of Caste, Class and Power in District Pulwama in South Kashmir
}

\author{
Irshad Ahmad Wani ${ }^{\text {i } \& ~ S . M . ~ Z u b e r ~}{ }^{2}$ \\ ${ }^{I}$ Department of Sociology University of Kashmir \\ ${ }^{2}$ The Himalayan Ecological \& Conservation Research Foundation, $J \& K$
}

\begin{abstract}
In recent times some attention is being paid to the study of social stratification and modes of life prevailing among Muslims in India. This study is also an attempt to study social stratification among Muslims in Kashmiri society. This Article on Kashmiri society is studied on the basis of Caste, Class and Power. Caste system is radically different from Caste system in Indian society. The rigid aspect is missing and very few people are ready to attach any importance to ascribed status. In Kashmir Class is the base of social stratification and most of the times its bases are economic. There are three fold divisions of kashmiri society, Syeds, 'Pirs', 'Ulemas', and 'Sheikhs' at the top, 'Dom', 'Wattals', at the bottom and rest in the Middle Class. However, the process of Modernization, secularization, education and new found economic prosperity has made the lines of demarcation very blur and flexibility is quite visible while analyzing social stratification in Kashmiri society.

Keywords: Social Stratification, Education, Social change, Syeds, Lower castes, Kashmiri Society.
\end{abstract}

\section{Introduction:}

If we endeavour to transgress the ambits of time and look retrospectively back on the history of human civilization, our sight will never miss the fragrant truth that the history of social stratification is of the same age as human civilization. The history of social stratification can be traced back to the times "when human switched their interest from" fishing or hunting to sedentary agricultural societies with a surplus economy, a variety of occupations developed that were essential to the proper functioning of that society (Frank, 1995). Inevitably, these functions began to be ranked hierarchically, usually based on the amount of preparation \& training needed or the importance of that occupation to a particular society.

Most people would agree that few societies are really equal. Ideally we want to believe as Thomas Jefferson wrote in the Declaration of Independence we hold these truths to be self-evident, that all men are created equal......" .But in the real world that is not always the case because some individuals have greater access to the scarce resources of society. Society is this built upon the relationships between the various unequal parts (Ramon and Robert, 2000). So, we know that societies have the internal inequality which may be termed as social stratification.

The study of social stratification is of central concern to sociologists because modern societies display such a wide range of inequalities. These include inequalities between rich and poor, between social classes, between men and women, and between black and white. Inequalities in wide range in almost every area of social life, such as in job security, leisure opportunities, health, housing, income and the power to influence events in society (Browne, 2005).

The word stratification is basically a Geological word, which means different layers which some rocks are having (Horton \& Horton, 1982). Borrowed by analogy from the Earth Sciences, the term social stratification has come into general sociological use only since about 1940 to denote exactly the same type of layers of the society (Sills, 1998). Thus, the term social stratification refers to the existence of different layers, which are created on the basis of unequal positions occupied by the members in a society, the unequal distribution of wealth, power and prestige provides the basis for the creation of different layers or strata in a society. The members of stratum generally have a common awareness, identity, life styles and chances (Sahoo, 2006).

Social stratification deals with the ways in which human population is socially differentiated i.e.' differentiated publicly and demonstrably. The criteria for differentiation may be one but the social display of differentiation usually include a host of factors including, Race, religion, family, lineage, kind and amount of property or income, occupation, or some other characteristics. Thus, the process by which individuals and groups are ranked in a more or less enduring hierarchy of status is known as social stratification (Ogburn \& Nimkoff, 1940).

From the very beginning, sociologists have tried to seek the roots, origin and rationales of the phenomenon. In fact, controversies are the natural outcome of the search for the higher orders of explanations and inclusive system of classification of this phenomenon. The differencing value systems, perception of social 
orders, equality and justice have led them, to provide different explanation. The distinction made between social inequality and natural inequality puzzled the analyses. Rousseau made first distinctions between the two and argued that the first one is established by nature and consists of difference in fate, health, bodily strength, and the qualities of mind or the soul. Similarly, social based inequality according to him consists of the different privileges which some men enjoy, to the prejudice of others such as, that of being richer, more honoured, more powerful, or even in a position to concrete obedience (Sahoo, 2006).

Social stratification / social inequalities exist in all types of human societies. Even the simplest cultures, were variations in wealth or property are virtually non-existent, there are inequalities between individuals, men and women, the young and old. A person may have a higher status than others, because of, particulars prowess at hunting, or because he /she have special access to the ancestral spirits. To describe inequalities, sociologists speak social stratification. Stratification can be defined as structured in equalities between different groupings of people (Giddens, 1997).

The systems of social stratification exhibit wide variance in different societies of the world. This variation may be in the criteria, utilized for placing individual and groups in various social strata of the system, or in the number of strata in the system, and with some having two broad strata such as, feudal lords and serfs, or nobility and commoners and other's having more. There may be flexibility and the sharpness with which each stratum are demarcated. In some systems different strata are easily identifiable, while in others the boundaries are hard to locate. Considering the various societies that have existed and do exist in the world, certain recurrent forms of social stratification generally van be identified. Sociologists have identified four major types or stratification system, which have different differences between them, the Slavery, the Feudal Estates, the Caste and the Class system.

\section{Significance of the Study}

There is a lot of literature available on the theme of social stratification in India. In fact, the most researched area in the Indian sociology deals, directly or indirectly with the social stratification or caste. In this regard, the Indian society has been studied both by the local sociologists as well as the alien sociologists. The focus of these studies has been on the origin, dynamics, implications and change in the caste system. Moreover, there have also been numerous surveys which were conducted on the literature available in the broader theme of social stratification including caste in India (In this regard see I.C.S.S.R Survey of research). The rise of Indian sociology owes its origin mainly to the interest in understanding Hindu Social Organization and the typical caste institution. A large of Indian as well as western sociologists interested in understanding Indian society have paid special attention to the analysis of the traditional caste system and the changes taking place therein. But along with this interest in Hindu social life, some attention is also now being paid to understand the socio-cultural life of Muslim community who constitute the largest minority of the country. In this way the sociological study of Muslims has also come to the forefront in the development of sociological literature in India today. Beteille (1965) has contributed immensely in this field. Andre Beteille's study of village Sripurum in Tamil Nadu is based on the assumption of a rational distinction between caste, class and power, changing relation of stratification in Tanjore District, brought to light the traditional caste structures as well as the forces of change that were making way into it. The major contributions of Indian as well as foreign sociologists in the field of social stratification are: Beteille, 1974; Singh, 1974; Menchar, 1979; Pandit, 1979; Srinivas, 1966; Powell, 1896; Toothis, 1935; Ghurye, 1932; Iyers, 1909-12; Desai, 1912; Bailey, 1957- 60; Berreman, 1960; Beteille, 1965; Chauhan, 1967; Dube, 1958; Majumdar, 1958; Madan, 1965; Mukherjee, 1957; Orenstein, 1965; Bose, 1968; Leach, 1960; Ansari, 1960; Dumont, 1961; Risley, 1961; Ahmad, 1962; D'Souza, 1962; Bailey, 1965; Marriot, 1968; Nesfield, 1985; Webber, 1952; Kroeber, 1930; Dubois, 1960; Singh, 1978; Gough, 1979; Singh, 1979; Jha, 1970; Bose, 1981; Iye, 1985; Nandu Ram, 1986; Sharma, 1986; Ehsan, 1981; Vashista, 1992; and Beteille, 2002.

The present study also throws light on the contributions made by sociologists towards understanding social stratification and forms of inequality in India. The literature generated by Indian sociologists is divided into decades starting from 1950 onwards. In these years many sociologists have put forward their views on social stratification. In 1950-60, M.N. Srinivas, G.S. Ghurye, S.C. Dube, R.K. Mukherjee, K.S. Mathur, H. Orenstein and many more, is taken up for analysis. They argued caste system is the sole institution of social ranking. Their theories are known as 'caste model of Indian society. The decade of 1960-70 saw few studies on social differentiation, evolution and change in caste and class. These sociologists have taken up studies from structural historical perspective particularly of agrarian and industrial stratification. These studies have been taken by E.R. Leach, victor D'Souza, Andre Beteille, L. Dumont, M. Marriot, A.R. Desai, and N.K. Bose etc in this regard. The decade 1970-80 has contributed richly to the emergence of new substantive and theoretical concern in the study of social stratification. Many sociologists have contributed for the further understanding of social stratification; these were Y. Singh, K.L Sharma, T.N. Madan, K. Gough, Nirmal Singh, Dhanagare, Zarina Bhatty, A. jha etc. During the period of 1980's-90's an important development has been the rich impute of the study of social 
stratification, the new emerging consciousness of the mobile classes among the weaker sections of the Indian society. Both the conceptual and methodological studies were carried out by many sociologists these are P.K. Bose, Klass, H.A. Lye, Dipankar Gupta, Ehsan-ul Haq, A.M. Shah, A.F.I Ali, Nandu Ram etc. Besides these sociologists there were other sociologists, who in 1990's-2002 have talked about the transformation of class structure in contemporary India, in which class formation, class disintegration, and class conflict has become important in the process of change in class structure. These are P.K. Bose, R.K. Shukla, V.K. Vashista, S. Jaswal, and Andre Beteille.

Beteille (1969) has contributed immensely in this field. Andre Beteilles study of "village "Sripurum" in Tamil Nadu' is based on the assumption of a rational distinction between caste, class \& power, changing relation of stratification in Tanjore District, brought to light the traditional caste structure as well as the forces of change that were making way into it. According to Beteille, Sripurum village is an agrarian village. The whole village is dominated by the king of the Brahmin to look after the temples and other building of the village. In Tanjore he finds caste system of the village to be more rigid and complex. The caste system, apart from determining the unequal ritual status of villagers, also dominates their political and economic life. The social life of the village has also structured on caste lines. The settlement pattern of the village has also evolved on caste lines. The people of Sripurum divide the many castes of Hindu into three subdivisions- "Brahmins", "NonBrahmins" and the Adi-Dravidas" are clearly segregated from one another in the village. The settlement pattern of the village continues to reflect the basic division of the traditional caste structure. The study finds that in Tanjore, the ownership of land is not only a source of wealth; it is also a source of prestige and power. The study also finds the class structure, which is largely vertical. The class system comprises of three economic units in the society, (1) "Brahmins Landowner", (2) Non-Brahmins, (tenants of Brahmins") (3) and "Adi-Dravidas, or Original Dravidas" (Sub-tenants or Agriculturalists or labour) and their mutual relations. In the social stratification system, Brahmins were at the top stratum of the society, Non-Brahmins were next to them, and Adi-Dravidian was at the bottom of the social stratification. They were treated as untouchables. Caste, class \& power, relate in different ways to the broader phenomenon of social stratification.

In the political sphere, or say in the village panchayats, Brahmins were occupying the power. They decided the dispute within the village. Before 1920, the Brahmin group was enjoying the political power. "NonBrahmins" \& "Adi-Dravidians" were having no say in the village panchayat. Andre Beteille calls it cumulative inequality. The study finds that in comparison to the rigidity of the institution of caste as well as stability of the traditional economic structure of the village, the distribution of political power has witnessed a radical change. The study found that caste, class and power were closely interwoven in the village. They could be treated separately only by a process of abstraction, caste and power in Sripurum village referred in different ways to the same phenomenon of social stratification (Beteille, 1969).

Yogendra Singh's name as well as his contribution stands at the top rung with regard to the study of social stratification in general and in India particular. Yogendra Singh argued that the theoretical position of caste constituted both a structural unit of social stratification as well as a system. Sociologists who looked across the cultural view of caste associated it with an autonomous principle of stratification, which are, institutionalized inequality, social system of social mobility, an elementary level of division of labour legitimized on ritual bases of reciprocity, and emphasis on quality, (ritual purity or racial purity) rather than performance in other words, caste is associated with an autonomous form of cultural system or world view (Singh, Yogendra, 1980). In this regard he quotes, "A. Nesfield" (1885), Max Weber (1952), A.L. Kroeber, (1930) and A' Dubois, 1960 etc. Moreover, in the writings of "Kingsley Davis", (1951) A.R. Desai, (1966) and N.K. Bose (1968) and others, caste was considered a structural reality which would disappear when the society in India reaches to a higher level. He made a distinction between sociologist who treat caste as a cultural phenomenon and those who define it as a structural phenomenon.

India was a static society where not change but continuity of a primitive culture was the dominant feature. This view was also supported by the early writings of Karl Marx. So in analyzing Indian class stratification, it was not considered worthwhile to take into account the present day processes among the various social strata. Studies on the traditional Indian society revealed that the class structure was related to the "mode of production", and "ownership of property", "growth of cities", "markets and Banking instructions", and "the institutions of power". This led to the emergence of various class categories. It was also analyzed how the forms/ structures of class changed in various historical stages of development.

There are also a few studies in which differentiation, evolution and change in caste and class over a period of time have been focused. The emphasis in these studies could be seen in "caste", "caste and class" "class alone", "again caste" and now "caste and class", as parts of social formation.

Another area of significant research, besides sociologists and social anthropologists, in which historians and economists have taken up studies from structural- historical stratification particularly of the industrial \& agrarian stratification and modes of production in agriculture vis-à-vis rural class structure and its changing patterns due to various aspects of change. 
A number of studies have also been conducted on Indian Muslims in different parts of the country. In the beginning these studies were conducted by social Historians and social Anthropologists. Later on, sociologists also joining in analyzing and understanding different aspects of community life among Muslims and these studies were generally micro-sociological in nature concentrating mainly on the analysis of Muslim communities living in specific villages, towns or localities. These throw some light on various aspects like patterns of stratification and local hierarchy, family and marriage, economic organizations, religious attachment and degree of religiosity, virtual and festivities and patterns of interaction in Muslim community. Moreover in course of such studies efforts have also been made to find out the impact of traditional Hindu Culture, deviation from Islamic sanctions, acceptance of western values and exposure to the forces of modernity in Muslim community. Thus, such studies on Muslim communities, no doubt, provide materials on different aspects of social life in the context of the past tradition as well as the present phase of transition.

The important studies in this field are those by; Ghaus Ansari, 1959; S.C. Misra, 1964; M. R. Siddiqui, 1974; Imtiyaz Ahmad, 1973; Zeyauddin Ahmad, 1977; Saghir Ahmad, 1977; S. M. Raza, 1976; Ali Ashraf, S.M. Raza, 1976, P.C. Aggarwal, 1973; Victor D’Souza, Zarina Bhatty, Hamza Ali, T.N. Madan etc.

The revelation made by most of these studies on various trends and patterns of social stratification that these studies were caste - oriented and caste based. Caste being the sole basis of social stratification, but not the only dominating factor, as for classes like political elites, new capitalists, bureaucrats, technocrats and others were emerging as factors for social inequality in past 1947 scenario. It is very clear that the sociologist failed to address these factors and also the cause of their emergence. The result of it was that sociologist's studies caste stratification devoid of above mentioned factors have distorted the reality and the actuality of the situation did not come into light. The sociologists thus, were not able to analyze the role of these factors.

Sociologists did not attribute to highlight the nature of social stratification in urban areas. The study on social stratification in urban areas was not on large scale. With the result, the phenomenon of social stratification in urban areas remained far from total revelation. It is also worth mentioning that urban context does not allow caste factor to determine comparatively. So, the need was to look forward with existential realities related to social stratification in urban areas.

Like all other societies, in Kashmir also there exist various forms of social stratification among the Muslim community. However, historically a shift it witnessed from one form of stratification to other. According to the 1921 census of India, majority of the Muslims in the Indian sub - continent in general and Kashmir in particular are the descendents of locals who changed their religion from Hinduism to Islam. Hence some Muslims and non Muslims say that these local Muslims who originally entered individually or in large groups consciously or unconsciously brought into their practice of Islam, their former Hindu caste practices and customs. With the course of time and advent of Dogra rule in Kashmir, the Muslims of Kashmir came under the oppression of the rulers that divided the people in to two classes: landlords and the working class resulting in prominent stratification based on the property and agriculture.

The abolition of Zamindari system, modern education, migration from rural to urban areas, changing political attitudes, etc. have produced far - reaching impact on the attitudes, life styles, usages, customary practices and mode of economic life among the Muslims in Kashmir in modern times as well as the impact of Islamic sanctions on the traditional community.

Enormous literature exists on social stratification and its various parameters. The origin and evolution of social stratification at international, national and regional levels have been studied in spatio-temporal perspective. The ancient, medieval and modern literature on it, have been thoroughly received and analyzed, the social stratification, its nature and structure, has also been elaborately studied by sociologists, Anthropologist and ethnographers. But such studies are confined to the social stratification among the Hindus.

A large number of Indian as well as western sociologists and social anthropologists interested in understanding Indian society have paid specific attention to the analysis of traditional caste system and the changes taking place therein. But such studies are confined on the Hindu society and culture, and through insufficient light on different aspects of social life or particularly social stratification among Indian Muslims. The empirical realities demand that the social stratification may also be studied among the non-Hindu in India.

In the recent time some attention is being paid to the study of social stratification and modes of social life prevailing among Muslims in India. But a comprehensive study of a Muslim community in India is still awaited. In this way the sociological study of Muslim has also come to the forefront in the development of sociological literature in India today.

It is clear from the above mentioned facts that there is a dearth of data/material as well as of sociologists and social anthropologist's who have taken interest in this (Social Stratification) study. It is therefore, a matter of some satisfaction that the collection of some papers in Imtiyaz Ahmad's book has succeeded in bringing together papers covering most of the areas significant Muslims concentration in India, excluding Kashmiri society from the coverage in these papers because this field is completely unexplored so far. So, this study is an attempt to explore this cruel social reality. 
Hence a sociological study of social stratification among Kashmiri Muslims is of great importance/significance and requires systematic enquiry modes of investigation for understanding the traditional modes of life, the social changes in modern times as well as the impact of Islamic sanctions on the traditional community life. The focus of the study will provide a comprehensive picture of the patterns of social stratification among Kashmiri Muslims. The study will also try to throw light on variation/similarity between other areas of Kashmir. It will help us in understanding of how social stratification arise, how they are sustained, how they change over time, and what are their consequences for a range of social and personal goals.

\section{Theoretical Perspective}

Two broad sociological approaches to explain and interpret social stratification have been discussed. They were functional and conflict. According to functional theorists, social stratification brings about harmony and integration in society by filling the basic needs. The conflict approach emphasizes the role of class, class conflict, and class consciousness in social stratification.

Talcott Parson's theory of Social Stratification is based on the unequal difference of different individuals with regard to different values of society. Thus, those who perform well in terms of societies value system are ranked higher with corresponding rewards and honour, others who do not come up to their level are ranked with less rewards and honour (M. Haralambos, 1997 P.31).

Marx argued social stratification as divisible rather than an integrated structure. He explains the course of historical development in terms of conflict between the two contending classes (Richard T. Shaffer $-\left(6^{\text {th }} \mathrm{Ed}\right)$ 2006 P. 207.). Max Webber's view has similarity with that of Marx and he considers class as a crucial and important aspect of social stratification. Webber says prestige and power of the economic aspect are two dimensions of social stratification. Webber's model of social stratification was based on the concept of Class, Status, and Party (Frank. N. Magill, 1995 Vol. 2 op. cit., P. 1282).

There is a harvest of theories essaying and expediting on the concept of social stratification, but none of the theories encompasses the whole cause and concept of social stratification. Prominent among these theories are conflict theory and functionalist theory. These two approaches condensed themselves only to one variable as mentioned above. That is to say that the conflict theory views social stratification as the outcome of economic inequality in a society; and functionalists view that social stratification is functional to the society.

But an Eminent sociologist Max Webber holds a different view. He agreed with certain fundamental features of Marxist thought, particularly with the crucial significance of the economic aspects of Stratification. For Webber, as for Marx, control over property was a basic fact in the determination of the life chances of an individual or a class. In contrast to Marx, however, Webber added to the economic dimension of stratification two other dimensions, power and prestige. Musing meticulously over the theories as hinted at above, the conflict and functionalist theory are not cogent approaches, to give us an all inclusive concept of social stratification. On the other hand, it is Max Webber who seems to indicate an approach to study social stratification which takes care of so many dimensions, factors or variables into account. It is because of this fact that class, status and power are prominent variables of the District Pulwama stratification here. Thus, the Weberian approach to social stratification has more relevance to our study. So, the social stratification of District Pulwama will be analyzed within the frame work of three variables i.e., caste, class and power.

\section{Methodology}

Studying human life and human society is and has been a particular subject of some of the prolific philosophers and intellectuals. The proposed study is on a simple but an important topic i.e., social stratification. The topic has been dealt with many a time before but the researchers have either concluded on undertaking limited group of people or have not highlighted all the facts related to it. Thus, there is always a scope for more and more research on this particular topic.

\section{Hypothesis}

Like in all human societies of the world, the Kashmiri society has developed certain pattern of social stratification. The existing pattern of social stratification in the Kashmir has under gone certain degree of qualitative as well as quantitative change mainly due to the impact of process of modernization, secularization, spread of education and new found economic prosperity.

\section{Universe and Sample of the Study}

The universe or the population is aggregate of all units, possessing certain specific characteristics of which the sample seeks to draw conclusions. The universe of the study means exact area where from the individuals for the sample are selected. The universe for this study is the District Pulwama of the Kashmir Valley. 
The choice of District Pulwama as the universe of the study was selected because this area is completely unexplored and no such study has been conducted which will provide information regarding the patterns of social stratification and secondly, researcher's personal acquaintance with the place and familiarity with its languages and peoples way of life.

\section{The Collection of Data}

Collection of data for the study under reference began with secondary sources. The information gathered from secondary sources provided an in-depth understanding of the historical account of the patterns of social stratification and forms of inequality prevalent in Kashmiri society. These sources proved fruitful in building some theoretical assumptions and parameters for the method of inquiry. Before going the field and actually interviewing people the study began with pilot study which starts before the field work. For pilot study, researcher took 50 families from different areas, and caste group to know the real patterns of social stratification present in district Pulwama and also understands the changes that have taken place in the social stratification of Pulwama district. The analysis of the pilot study helped the researcher to form the basis of an outline including the desirable items to be included in the in-depth study of social stratification in Pulwama District. On the basis of this pilot study, a sample of 100 households was selected accordingly. Thereafter, field work was carried out by the researcher. An interview Guide was used as a tool for data collection.

Finally the research findings were written in an elaborate, as a report. Thus, the information collected from primary and secondary sources about the patterns of social stratification in district Pulwama was put in pre-determined theoretical framework which became the basis of our observation in the findings. These findings were analyzed in the sociological framework and conclusion were drawn in relation to the findings on which hypothesis were based. Researcher was also conscious about the bias which generally creeps in the study framework. Hence, by the scientific method such problems were solved and the desired goals were achieved."

\section{Results and Discussions}

The district Pulwama as a representative type of the Kashmir society resembles with the broader social structure prevailing in the valley of Kashmir. The universe of the study is stratified on the basis of 'caste, class and power'. But at present, the individuals here are differentiated on the basis of income, landholding, occupation, education and power.

The analysis of the information gathered from secondary sources as well as primary sources i.e., responses of the people revealed that social stratification in district Pulwama may be explained in terms of 'caste, class, and power'. Theoretically speaking, Islam as a form of religion has never uphold or allowed caste, creed, and colour as the basis of social hierarchy / inequality. But from the empirical point of view, Muslims all over the world and in this district too are stratified, In some societies, on the basis of caste (Indian subcontinent), in other societies on the basis of social and economic standing (Developed societies). So, the district Pulwama being part of the broader Indian sub-continent is also stratified on the basis of 'caste, class, and power.

\section{Caste Stratification}

Caste first came to be identified as a principle of social stratification among Hindus. It has remained a dominant feature of social stratification in the Indian sub-continent. Sociologists have always tried to explain and analyze the social stratification in India in terms of caste. Moreover, while analyzing systems of social stratification in other religions and societies, they tend quite unconsciously to follow a culture-specific definition of the institution and base their discussion on the Hindu phenomenon. The Kashmiri society, being a part of the broader Indian society, has also been influenced by this caste system. In pre-Islamic period, the valley was wholly peopled with Hindus, in which the Brahmans were at the top of the social hierarchy because they were considered the most knowledgeable person. The enjoyed the superiority and exploited the lower castes (Shudr) for their vested interests. But it was only after the $14^{\text {the }}$ century, when Muslim saints reached here and started their mission by converting the people (Hindus) in to the Islamic religion. They taught the basic philosophy of Islam, which is based on the equality of all. It is because of this egalitarian philosophy, most of Pundits' convert into Muslims and had a sigh of relief of the oppression which they had faced in the typical Hindu caste system. The Islamic religion, when we see from the strict theoretical sense, is without the caste barriers. In fact, it negates the very notion of caste stratification. It generally emphasizes on egalitarian system, the holey Quran says:

O mankind! We (God) created you from a single pair of male and female and made you into peoples and tribes, that ye may know each other (not despise each other). Verily, the most honoured in the sight of God is (he who is) the righteous among you............... (Surah Al-hujuraat verse-13)

This verse makes it quite clear that though Islam accepts differentiation based on gender and tribe. It does not recognize social stratification. It clearly opposes to draw the line of demarcation on the basis of race, colour, creed and caste. But, at the same time, it is true only up to the theoretical understanding of Islam. But in reality, 
the Muslim community remains diversified, fragmented and as caste-ridden as any other community of India. Practically, the situation in the Muslim society is somewhat different. Muslims too are stratified on the basis of caste. There had been always an element of superiority present with those castes which are considered to be at top, and a kind of inferiority present with those castes which are considered to be at the bottom.

The finding of the present study undertakes an analysis of the social stratification among the Muslims of district Pulwama. The study of stratification in the Pulwama throws light on social hierarchy and the attitude of people in respect of discriminatory behaviour and inequalities found among Muslims, though Islamic sanctions do not support any form of stratification or social hierarchy among the believers in Islam. Descent and hereditary is not at all a consideration for determining the place and position of the individual in an Islamic society. Only piety and virtuous qualities are the bases for differentiating the people. This differentiation is not associated with the distribution of social status. In the traditional society this ideal sanction of Islam did not remain operative. The Islamic norms became ideal and the operative norms recognized distinction between man and man on the bases of religions knowledge. The Muslim society like the traditional Hindu society got divided into different status groups on the lineage and descent.

The facts collected from the field indicated that within the traditional structure of the Pulwama, Syeds, Pirs, and Ulemas, used to dominate the life of the people as a whole. As it is believed that they are the descendants' of Prophet Muhammad (PBUH) that they are the people who have brought Islam in this society, and that they were the only people who were having good religious knowledge.; so, the masses in general were giving them good respect and treated them as' Superior', human beings. But at present the monopoly of this group has been challenged because of them modern education, modernization, secularization, and new found economic prosperity. In the past, people completely follow their teachings and considered them the sole preaching class. This particular class occupied the top most position in the hierarchical arrangements. They used to settle down the village disputes including domestic ones as well. The social status of Syeds was ascribed one. They maintained their social identity and status by the religi9ous preaching and foreign ancestry. But at present people follow them partly, because they have now better religious knowledge than Syeds. People also think that Syeds don't remain confined to their religious work and they also take participation in other social and political activities.

Another reason for it that in present age the distance between upper and lower castes is narrowing and greater frequency of interaction is found, Although the sense of superiority on the basis of lineage is still persisting but not with the same zeal and consciousness. People of lower caste enjoying better economic portion and having better educational background are being treated at par with the members of upper caste people. The only institution where lineages still persists is at the time of steeling marriages of their wards. The Syeds do not like marital relations with low3 caste people no marriage in the area of study was reported between the high caste boy and girl with counterpart in the lower scats. Hence, the caste restriction and lineage distinctions are taken in to consideration only on the occasion of fixing marriages.

\section{Class Stratification}

The Pulwama society is presently class-based rather than caste based. People at present are stratified on the basis of class. Some are place at the top of the hierarchy; some at the bottom and rest in between. This system is explained in terms of class, particularly an economic class. People in the past were differentiating on the basis or large land holding and religious knowledge. But, at present it is not the land holding, but the monthly income of the person which differentiates families from one another. Now it is one's income which determines his/her social position or status in the society. Economic class is purely seen in relation to the property, nature of service, trade, business and the standard of living, but belonging to a higher caste gives additional status to the person.

The class structure of district Pulwama is aptly reflected by the agrarian class structure. The economy of the Pulwama division was based primarily upon agriculture and hence the relation of production depends upon the process of agriculture, such categories Include, landlords, cultivators, tenants \& agricultural labourers. So, this indicates that in Pulwama class stratification was based upon the landholding. In district Pulwama, those who owns the land was called, 'Zamindars' (Land lords') \& those who don't were called as 'Nangars (Landless/serf's). This system of class stratification was known as 'Shaksi or Shaksiyaatic Raj" (feudalism), in which the Zamindars (landlords) were at the top \& the Nangars (landless peasants) were at the lowest wrung.

\section{Power Stratification}

The study further indicates the emergence of new bases of power. The findings in this connection show that in the past there was correlation between the land ownership and the power. People who were possessing large size of land were at the same time monopolizing power in the society. The people holding large size of land were called Zaildars. The Zaildar was the absolute authority in the village and the masses (tenants) always obeying his orders to avoid the harm which he was capable of inflicting. This pattern of power structure in the 
Pulwama continued up to 1947. The political climate of India as well as of Kashmir has been changing fast since the very beginning of the $20^{\text {th }}$ century.

After independence, new bases of power emerged. The findings in this connection show that out of many bases that are perceived to determine power, "land and wealth" gets the first rank followed by education "having a large following political connection, belonging to a higher caste and capacity to use physical force in order of preference. In the past, large size of land holding and physical strength of an individual was determinant of power in the society. They were called "Zaildars". This power structure was called as "Shaksi Raj "(i.e., feudalism). Power is the dominating feature of social stratification in rural Kashmir. It has to do less with land holding as was the cast in the past. In fact, power is followed by class and the basis of which are property, trade and business. In the present era, the old basis of power has been replaced by ones relation with political parties which coincide with economic position.

After the achievement of independence the parliamentary form of the democracy facilitated the common people to participate in politics not only as voter but also as a candidate as well as campaigner or organizer of election campaign. Because of that, drastic changes were experienced in the power structure soon. The major reason for this change was the abolition of Zamindari system and the introduction of land reforms acts in 1952.

\section{Changes in Social Stratification}

After independence and contact with developed countries, tremendous changes have been experienced in the overall structure of the Kashmir society. Such changes had left no area unaffected. In rural areas as compared to urban areas the change has been a bit slow. It is because of illiteracy, ignorance and the lack of opportunities to the rural people. Another factor is that the rural people are superstitious \& religious dogmatic which is not the case in urban areas.

In the past, patterns of living in this area were determined by land holdings, religious knowledge and traditional practices. But the facts collected from the field suggest that past patterns of differentiation has started changing gradually due to the changes in the relational and institutional aspects of community life.

As we have already mentioned, that Islam do not support any form of stratification or social hierarchy among its believers. Descent or hereditary is not at all a consideration for determining the status and position of the individual in an Islamic society. Only piety and virtuous qualities are the bases for differentiating the people, and this differentiation is not associated with the distribution of social status. But in the traditional society this ideal sanction of Islam did not remain operative. After conversion, people differentiate one another on the basis of descent and lineage. 'Syeds, 'Pirs' \& 'Ulemas' sat at the top, because of their foreign ancestry \& religious knowledge, where as the 'Wattals', 'Wagays', \& 'Dums' at the lowest wrung because of their ignorance and occupation.

But in the present age the situation is changing. The distinctions between the upper and lower castes are narrowing and greater frequency of interaction is found between them. Presently the sense of superiority or domination on the basis of religious knowledge and foreign ancestry is still persisting but not with the same zeal and consciousness. Modernization, secularization, education \& new found economic prosperity has changed the attitude and actual practices regarding the ascribed and achieved status and prestige and facilitated social mobility. Social hierarchy is still persisting but the traditional form of rigid stratification is not in practice. This change in the patterns of social stratification and hierarchy is an index of change in the social structure of the area under study.

Again, Islamic sanctions do not divided the community in to different endogamous groups. But under the impact of traditional culture, the Muslims also developed a caste-like hierarchy and the concept of superior or inferior prevailed on the basis of birth, descent and religions knowledge. This was given due importance and Muslims also performed marriages within the same castes. But after independence, different caste people work shoulder to shoulder in day to day activities but in spite of that people still follow the very tradition in the matters of mate selection. At present within caste marriages occur. This is the only institution where caste system still plays a vital role.

After modernization things got better and better every day in our state as well as in the area under study. The area of Pulwama has always prone to the adoption of social changes. It is primarily because majority of the people are earn their livelihood from the broader economic activities present here $\&$ in other parts of the $\mathrm{J} \& \mathrm{~K}$. In the past, the vast majority of the population was dependent on agriculture. So, the social stratification was primarily based on how much land one owns. But, this kind of social stratification has gone through basic change. People have switched over to trade, business and government services. The whole exploitative and dehumanizing system diminished. Spread of education, land reform acts, reservation for lower castes, democratic ideas, and new found economic prosperity changed the traditional pattern of social stratification. Due to change in peoples standard of living, had made them conscious about the exploitation they faced by the hands of upper castes. At present it is not one's caste, religious knowledge, land holding, residence, occupation 
or physical strength, but one's monthly income, the style of life or achievements and education which determines his status. All the past criteria had shedded in this society. But still, only at the time of marriage the effect of caste system or prevailing of caste system comes into being.

In district Pulwama, old bases of power such as the high rank on caste hierarchy and the landed property have decreased. The rise and development of political awareness and political consciousness among the villagers are found these days. This rise of political awareness is an index of changing political relations and thus the change in the structure of this society. New sources of power like political affiliation and education are emerging fast. The lower castes are also having equal say in the present political system which was not the case in Maharaja's reign. Most of the disputes in district Pulwama are referred to the court of law. It is also important to keep in mind that the whole Kashmir as well as the area of study is captured by the terrorists, but in spite of that people are participating freely in the elections.

Finally family, caste and religions knowledge do play important role in the forms of social stratification. But the dominating factors which stratify the Pulwama society are monthly income, education, and political connections. Because of this, Pulwama society is becoming class-based rather caste-based, and importance of land holding in determining the power of the family has been replaced by wealth.

\section{Summary and Conclusions}

This study is an attempt to study the broad patterns of social stratification prevailing in district Pulwama. As a complex social phenomenon, social stratification which refers to the division of the society into various hierarchical strata is as old as human civilization, while many have talked about a 'classless' societies of either the past or the future, but these ideas found very little support in historical experience. Though the phenomenon is common to all societies but its nature and forms vary from society to society, and from culture to culture.

After independence and contact with developed countries, tremendous changes have been experienced in the overall structure of the Kashmir society. Such changes had left no area unaffected. In rural areas as compared to urban areas the change has been a bit slow. It is because of illiteracy, ignorance and the lack of opportunities to the rural people. Another factor is that the rural people are superstitious and religious dogmatic which is not the case in urban areas.

In the past, patterns of living in this area were determined by land holdings religious knowledge and traditional practices . But the facts collected from the field suggests that past patterns of differentiation has started changing gradually due to the changes in the relational and institutional aspects of community life.

As we have already mentioned, that Islam do not support any form of stratification or social hierarchy among its believers. Descent or hereditary is not at all a consideration for determining the status and position of the individual in an Islamic society. Only piety and virtuous qualities are the bases for differentiating the people, and this differentiation is not associated with the distribution of social status. But in the traditional society this ideal sanction of Islam did not remain operative. After conversion, people differentiate one another on the basis of descent and lineage. Syeds, Pir, and Ulemas sat at the top, because of their foreign ancestry and religious knowledge, where as the wattals, Wagays and Dums' at the lowest wrung because of their ignorance and occupation.

At present the situation is changing. Modernization, secularization, education and new found economic prosperity has changed the attitude and actual practices regarding the ascribed and achieved status and prestige and facilitated social mobility. Social hierarchy is still persisting but the traditional form of rigid stratification is not in practice. This change in the patterns of social stratification and hierarchy is an index of change in the social structure of the area under study.

Again, Islamic sanctions do not divided the community in to different endogamous groups, but under the impact of traditional culture, the Muslims also developed a caste-like hierarchy and the concept of superior or inferior prevailed on the basis of birth, descent and religious knowledge. This was given due importance and Muslims also performed marriages within the same castes. But after independence, different caste people work shoulder to shoulder in day today activities but in spite of that people still follow the very tradition in the matters of mate selection. At present within caste marriages occur. This is the only institution where caste system still plays a vital role.

After modernization things got better and better each day in our state as well as in the area under study. The area of Pulwama has always prone to the adoption of social changes. It is primarily because majority of the people are earning their livelihood from the broader economic activities present here and in other parts of the J\&K. In the past, the vast majority of the population was dependent on agriculture. So, the social stratification was primarily based on how much land one owns. But, this kind of social stratification has gone through basic change. People have switched over to trade, business and government services. The whole exploitative and dehumanizing system diminished. Spread of education, land reform acts, reservation for lower castes, democratic ideas, and new found economic prosperity changed the traditional pattern of social stratification. 
Due to change in peoples standard of living, had made them conscious about the exploitation they faced by the hands of upper castes. At present it is not one's caste, religious knowledge, land holding, residence, occupation or physical strength, but one's monthly income, the style of lire or achievements and education which determines his status. All the past criteria had shedded in this society. But still, only at the time of marriage the effect of caste system comes into being.

In district Pulwama, old bases of power such as the high rank on caste hierarchy and the landed property have decreased. The rise and development of political awareness and political consciousness among the villagers are found these days. This rise of political awareness is an index of changing political relations and thus the change in the structure of this society. New sources of power like political affiliation and education are emerging. In fact the lower castes are also having equal say in the present political system which was not the case in Maharaja's reign. Most of the disputes in district Pulwama are referred to the court of law. It is also important to keep in mind that the whole Kashmir as well as the area of study is captured by the terrorists, but in spite of that people are participating freely in the elections.

Finally, family, caste and religious knowledge do play important role in the forms of social stratification. But the dominating factors which stratify the Pulwama society are monthly income, education and political connections. Because of this, Pulwama society is becoming class-based rather caste-based, and importance of land holding in determining the power of the family has been replaced by wealth. At the same time, it is incorrect to say that the institution of caste has eroded. Higher caste status definitely increases the social standing of a person with higher income, education and political affiliation.

The finding of the study reveals that modernization, education, economic prosperity and mass media had a decisive impact on our society in general and social stratification in particular:-

- Education has been one of the major factors responsible for the change emerging in social stratification. In the past education was discouraged by religious heads (i.e., Syeds, Pirs, and Ulemas), because they believed that it goes against the teaching of Islam. But at present modern education is encouraged by the masses, this is evident by the fact that for higher education people moves to the other parts of the country. So, education has certainly helped in the mobility of the people.

- In the past, social stratification was primarily based on how much land one was holding. But this kind of social stratification has gone through basic changes. Now it is monthly income, nature of services, business and trade which determines ones position in the society.

- Modernization, secularization and economic independence of women have bought lots of changes in the society. Previously the women of Pulwama were mostly confined to the domestic activities, but due to the above mentioned factors, women are visible in every field, whether it is government service, business or any other economic activity. These changes are reflected in the changes taking place in their traditional family system and in marriage as well.

- Modern avenues of employment have changed the traditional economic structure. The economic competition among the members of the same caste or of other castes enable people to choose caste-free occupations and various means and diversified ways to earn more and more money and acquire property. They have crossed the boundaries of traditional division of labour. Truly speaking, the emergence of caste-free occupation has contributed towards dissociating class relations from caste structure.

- Mass media has also helped in bringing change in the pattern of social stratification. Media has greatly influenced different spheres of social life in the Pulwama society. Particularly after 2000, media played vital role in exploring different aspects of this society.

- The rural power is becoming more differentiated and dispersed because of the impact of modern political forces in contrast to the power structure which existed in the past. New sources of power like political connections and education have emerged because of the political modernization and industrialization.

\section{References}

[1]. Aggarwal, P.C. (1971): Caste, Religion and Power. SRCIR New Delhi.

[2]. Aggarwal, P.C. (1978): Caste Hierarchy in a Meo Village of Rajasthan. In: Caste and Social Stratification Among Muslims in India (Ed. Imtiyaz Ahmad), Manohar Publications New Delhi.

[3]. Ali, A.F.I. (1993): Changing Social Stratification in Rural Bangladesh. Common Wealth Publishers, New Delhi.

[4]. Ansari, G. (1960): Muslim caste in Uttar Pradesh; A study of culture Contact. National Publishing House, Lucknow.

[5]. Bailey, F. G. (1960): Tribe and Nation. Oxford Bombay.

[6]. Bailey, F. G. (1957): Caste and the Economic Frontier, Manchester University Press, Manchester.

[7]. Berreman, G.D. (1970): Caste and other inequalities; Essays on Inequality. Folklore Institute Meerut.

[8]. Beteille, A. (1965): Caste, Class and Power: Changing power of Social Stratification in a Tanjore Village. Oxford University Press Bombay.

[9]. Beteille, A. (1969). Caste, Class and Power. Bombay: Oxford University Press.

[10]. Beteille, A. (1969): Social Inequality. Penguin Books, Harmondswerth.

[11]. Beteille, A. (1972): Inequality and Social Change. Oxford University Press, New Delhi.

[12]. Beteille, A. (1975). Six Essays in Comparative Sociology. Delhi Oxford University Press. 
[13]. Bhatty, Z. (1978): Status and Power in a Muslim Dominated Village of Uttar Pradesh. In: Caste and Social Stratification among Muslims in India (Ed. Imtiyaz Ahmad). Manohar Publications Delhi.

[14]. Bose, N.K. (1975): Some Aspects of Caste in Bengal. In: Traditional India: Structure and Change (Ed. Milton Singer). Rawat Publication Jaipur.

[15]. Bose, P.K. (1979): Agrarian Structure, Peasant Society and Social Change: A Study of Selected Regions in West Bengal. PhD Thesis, JNU, New Delhi.

[16]. Bougle, C. (1971): Essays on the Caste System. Cambridge University Press, Cambridge.

[17]. Briggs, G.W. (1920): The Chammars. Oxford University Press, London.

[18]. Browne, K. (2005): An introduction to Sociology $3^{\text {rd }}$ Edition. Polity Press, pp. 11.

[19]. Chauhan, S.K. (1980): Social Stratification in Assam. Classical Publishing Company, New Delhi.

[20]. D’Souza, V. (1981): Inequality and its Perpetuation. Manohar Publications, New Delhi.

[21]. Desai, A. R. (1969): Rural Sociology in India. Popular Prakashan Bombay.

[22]. Desai, I.P. (1964): Some Aspects of Family in Mahuwa. Asia Publishing House Bombay.

[23]. Dhanagare, D.N. (1993): Themes and Perspectives in Indian Sociology. Rawat Publications Jaipur.

[24]. Dube, S.C. (1955): Indian Village. Routledge and Kegan Paul, London.

[25]. Dube, S.C. (1958): India's Changing villages. Cornell University Press Ithaca.

[26]. Dubois, A.J.A. (1981): Hindu Manners: Customs and Ceremonies. Oxford University Press, Delhi.

[27]. Dumont, L. (1970): Homo Hierarchicus. Paladin Granada Publishing Ltd. London.

[28]. Ghurye, G.S. (1957): Caste, Class and Occupation. Popular Book Depot. Bombay.

[29]. Ghurye, G.S. (1969): Caste and Race in India, Popular Prakashan, Bombay.

[30]. Giddens, A. (1997): Sociology $3^{\text {rd }}$ Edition. Polity Press Cambridge, pp. 240

[31]. Haralambos, M. and Holborn, M. (1997): Sociology Themes \& Perspectives. Harper Colins Publishers, New York.

[32]. Husain, M. and Haseena, H.M. (1989): Seasonal Migration of Kashmiri Labour. Pima Publishing House, New Delhi.

[33]. I.C.S.S.R's "A Survey of research in Sociology and social anthropology. Vol. I (Bombay, Popular Prakashan). This includes two trend reports, first by Surjit Sinha "Caste in India" and second by Yogendra Singh "Sociology of Social Stratification".

[34]. Imtiyaz, A. (1978): Caste and Social Stratification among Muslims in India. Manohar Publications, New Delhi.

[35]. Kingsley, D. (1951): The Population of India and Pakistan. Princeton University Princeton.

[36]. Leach, E.R. (1980): Aspects of Caste in South India, Ceylon and West Pakistan. Cambridge University Press, Cambridge.

[37]. Lindholm, C. (1996): "Caste in Islam and the Problem of Deviant Systems: A Critique of Recent Theory," in Frontier Perspectives: Essays in Comparative Anthropology, Oxford UP.

[38]. Madan, T.N. (1965): Family and Kinship: A Study of the Pandits of Rural Kashmir. Asia Publishing House Bombay.

[39]. Magill, F.N. (1995): International Encyclopaedia of Sociology, London Vol. 2, pp. 1262.

[40]. Majumdar, D.N. (1958): Caste and Communication in an Indian village. Asia Publishing House Bombay.

[41]. Marriot, M. (1965): Caste Ranking and Community, structure in Five Regions of India and Pakistan. Poona, Deccan College.

[42]. Mencher, J.P. (1974): The Caste System Upside Down or not-so-Mysterious. Current Anthropology, Vol. 15, No. 4.

[43]. Misra, B.B. (1961): The Indian Middle Class: Their Growth in Modern Times. Oxford University Press Delhi.

[44]. Morton, K. (1980): Caste: The Emergence of the South Asian Social System. Institute for the Study of Human Issues, Philadelphia.

[45]. Mukherjee, D.P. (1958): Diversities. People's Bookies Delhi.

[46]. Mukherjee, R.K. (1957): The Dynamics of a Rural Society; A Study of the Economic structure in General village. Berlin, Academic-Verlag.

[47]. Mukherjee, R.K. (1979): Sociology of Indian Sociology. Allied Publishers Bombay.

[48]. Ogburn, W.F. \& Nimkoff, M.F. (1940): Sociology. Cambridge University Press, pp. 157.

[49]. Horton, P.B. \& Horton, R.N. (1982): Introductory Sociology. Homewood, pp. 65.

[50]. Powel, B.H.B. (1896): Indian village community. Longmans London.

[51]. Ramon, G.S. and Robert, M.L. (2000): A Social World. Pearson Publication, pp.137.

[52]. Raza, S.M. (1976): Changing Pattern of Muslim Community in Bihar. PhD Thesis, Patna University.

[53]. Risley, H.H. (1891): The Tribes and Castes of Bengal. 2 Vols. Bengal Secretariat Press, Calcutta.

[54]. Risley, R.H. (1969): The Peoples of India $2^{\text {nd }}$ Ed. Orient Books, Delhi.

[55]. Sahoo, A.K. (2006): Trends in Sociology. Abhijeet Publication New Delhi, pp. 40.

[56]. Senart, E. (1980): Caste in India: The Facts and the System. Metheun \& Co. London.

[57]. Shaffer, R.T. (2006): Sociology $\left(6^{\text {th }}\right.$ Ed). Tata McGraw Hill Pub., New Delhi.

[58]. Shah, A.M. (1988): Division \& Hierarchy: An Overview of Caste in Gujarat, Hindustan Publishing Corner, Delhi.

[59]. Sharma, K.L. (1980): Essays on Social Stratification. Rawat Publications Jaipur.

[60]. Sills, D. (1998). Encyclopaedia of Social Sciences. Macmillan Press, Vol. 15, pp. 289.

[61]. Singh, K.S. (1985): Tribal Society in India: An Anthropo-historical Perspective. Manohar Publications Delhi.

[62]. Singh, Y. (1977): Social Stratification and Change in India. Manohar Publications New Delhi.

[63]. Singh, Y. (1980): Social Stratification and Social Change in India. Manohar Publications, New Delhi.

[64]. Singh, Y. (1985): Sociology of Social Stratification. In: Survey of Research in Sociology and Social Anthropology, ICSSR and Satvahan, New Delhi.

[65]. Srinivas, M.N. (1962): Caste in Modern India and Other Essays. Asia Publishing House Bombay.

[66]. Srinivas, M.N. (1986): Indian Social Structure. Hindustan Publishing Corporation Delhi India.

[67]. Weber, M. (1970): Caste, Class and Party. In: From Max Weber: Essays in Sociology (Eds. H.H Garth and C. Wright Mills). Routledge and Kegan Paul, London. 